\title{
Hepatocyte Collagen Production In Vivo in Normal Rats
}

\section{Mario Chojkier}

With the technical assistance of Michael Filip

Division of Gastroenterology, Department of Medicine, Veterans Administration Medical Center, San Diego,

California 92161; and University of California at San Diego, California 92093

\begin{abstract}
Although hepatocytes produce collagen in vitro, their contribution to hepatic collagen synthesis in vivo is unknown. To answer this question, we injected rats intraperitoneally with $\left[{ }^{3} \mathrm{H}\right]$ proline and $\left[{ }^{14} \mathrm{C}\right]$ ornithine. $\left[{ }^{3} \mathrm{H}\right]$ Proline labeled prolyl-t-RNA in both hepatocytes and nonparenchymal cells. In contrast, $\left[{ }^{14} \mathrm{Clornithine} \mathrm{was}\right.$ rapidly converted to $\left[{ }^{14} \mathrm{C}\right]$ arginine via the urea cycle only in hepatocytes, labeling arginyl-t-RNA. $\sim 60 \%$ of the ${ }^{14} \mathrm{C}$ in albumin and transferrin was present as arginine while the remainder was found in proline and related amino acids. As expected for proteins that have the same proline/arginine ratio and that are produced solely by the hepatocyte, the $\left[{ }^{3} \mathrm{H}\right]$ proline $/\left[{ }^{14} \mathrm{C}\right]$ arginine ratio was very similar in albumin and transferrin. Conversely, in nonparenchymal cells a negligible percentage of ${ }^{14} \mathrm{C}$ was present as arginine. A sizeable percentage of the ${ }^{14} \mathrm{C}$ in hepatic collagen was present as arginine; given the greater proline(+hydroxyproline)/arginine ratio in hepatic collagen, our data indicate that in normal rats, hepatocytes contribute most of newly synthesized hepatic collagen.
\end{abstract}

\section{Introduction}

In cirrhotic livers, all collagen types present in normal livers are increased severalfold (1-3). Although hepatocytes (4-6) and nonparenchymal cells $(4,7-9)$ can produce collagen in vitro their relative contribution to hepatic collagen synthesis in vivo is unknown $(10,11)$. Obviously, the behavior of these cell types with regard to collagen production, when they are placed under the architectural and nutritional constraints of the intact organ, may bear no relation to their behavior in culture.

We devised a method to assess the hepatocyte contribution to in vivo hepatic collagen production. ${ }^{1}$ We injected rats intraperitoneally with a purified isotope mixture containing $\left[{ }^{3} \mathrm{H}\right]$ Pro and $\left[{ }^{14} \mathrm{C}\right]$ Orn (or $\left[{ }^{14} \mathrm{C}\right]$ Pro and $\left[{ }^{3} \mathrm{H}\right]$ Orn). Both labeled Pro and labeled Orn would be transported into hepatocytes and nonparenchymal cells. We reasoned that upon uptake $\left[{ }^{3} \mathrm{H}\right]$ Pro would

Portions of this work were presented at the 36th annual meeting of the American Association for the Study of Liver Diseases, and were published in abstract form (1985. Hepatology. 3:1040).

Address reprint requests to Dr. Chojkier, Gastroenterology Section (111D), Veterans Administration Medical Center, 3350 La Jolla Village Drive, San Diego, CA 92161.

Received for publication 8 January 1986.

1. The radioactivity present in collagen is considered to reflect net production resulting from incorporation during biosynthesis and loss due to degradation. It can be presented as: Production $=$ Biosynthesis - Degradation.

The Journal of Clinical Investigation, Inc.

Volume 78, August 1986, 333-339 label prolyl-t-RNA in both hepatocytes and nonparenchymal cells; and that only in the hepatocyte $\left[{ }^{14} \mathrm{C}\right]$ Orn would be rapidly converted, via the urea cycle to $\left[{ }^{14} \mathrm{C}\right] \operatorname{Arg}(12)$, labeling arginyl$t$-RNA. Because the nonparenchymal cells lack a complete urea cycle they would not produce $\left[{ }^{14} \mathrm{C}\right] \mathrm{Arg}$.

In consequence, proteins exclusively produced by the hepatocyte such as albumin (ALB) ${ }^{2}$ (13) and transferrin (TFR) (14) and any collagen if produced by this cell would be labeled with $\left[{ }^{3} \mathrm{H}\right]$ Pro and $\left[{ }^{14} \mathrm{C}\right] \mathrm{Arg}$. On the other hand, proteins produced by nonparenchymal cells including any collagen produced by these cells would contain $\left[{ }^{3} \mathrm{H}\right]$ Pro but not $\left[{ }^{14} \mathrm{C}\right]$ Arg. Proteins produced by both cell types would have an intermediate composition of labeled amino acids. We found that in normal rats, hepatocytes produce collagen in vivo and they contribute most of the newly synthesized hepatic collagen.

\section{Methods}

Materials. Uniformly labeled L- $\left[{ }^{14} \mathrm{C}\right]$ proline $(273 \mathrm{mCi} / \mathrm{mmol})$ and $\mathrm{L}-$ $\left[2,3-{ }^{3} \mathrm{H}\right]$ ornithine $(20 \mathrm{mCi} / \mathrm{mmol})$ were obtained from New England Nuclear, Boston, MA; and $\mathrm{L}-\left[1-{ }^{14} \mathrm{C}\right]$ ornithine $(55 \mathrm{mCi} / \mathrm{mmol}), \mathrm{L}-[5-$ ${ }^{3} \mathrm{H}$ ]proline ( $22 \mathrm{mCi} / \mathrm{mmol}$ ), and aqueous counting scintillant (ACS) fluid were from Amersham Corp., Arlington Heights, IL. Sources of other chemicals were: metrizamide (Grade I) and pepsin, from Sigma Chemical Co., St. Louis, MO; pronase, from Calbiochem-Behring Corp., La Jolla, $\mathrm{CA}$; rabbit anti-rat transferrin, from Cappel Laboratories, Cochranville, PA; phenylmethylsulfonyl fluoride, from Biotech Research Labs., Inc., Rockville, MD; ultra pure special enzyme grade ammonium sulfate, from Schwarz/Mann, Div., Becton-Dickinson \& Co., Orangeburg, NY; BCA protein assay reagent, albumin standard, and Brij 35 , from Pierce Chemical Co., Rockford, IL; ethyl alcohol, from Aaper Alcohol and Chemical Co., Shelbyville, KY; electrophoresis grade sodium dodecyl sulfate (SDS), urea, high molecular weight protein standards, AG50W$\times 8$ (100-200 mesh), Bio-Gel P-2 (100-200 mesh), Bio-Gel A 0.5 m, and Affigel-Blue (150-300 $\mu \mathrm{m}$ ), from Bio-Rad Laboratories, Richmond, CA; glacial acetic acid (AR), from Mallinckrodt, Inc., Paris, KY; and collagenase form III, from Advance Biofactures Corp., Lynbrook, NY. All other chemicals and biochemicals were commercially available analyticalgrade reagents.

Animal studies. Sprague-Dawley male rats (Charles River Breeding Laboratories, Inc., Wilmington, MA) weighing 170-225 g had their food removed $2 \mathrm{~h}$ before experimentation but had free access to water. Animals were injected intraperitoneally with $0.5 \mathrm{ml}$ of sterile saline containing $400 \mu \mathrm{Ci}$ of $\left[2,3-{ }^{3} \mathrm{H}\right]$ ornithine, or with a mixture of either $2 \mathrm{mCi}$ of [5$\left.{ }^{3} \mathrm{H}\right]$ proline and $130 \mu \mathrm{Ci}$ of $\left[1-{ }^{14} \mathrm{C}\right]$ ornithine, or $400 \mu \mathrm{Ci}$ of $\left[{ }^{14} \mathrm{C}\right]$ proline and $400 \mu \mathrm{Ci}$ of $\left[2,3-{ }^{3} \mathrm{H}\right]$ ornithine. One-half of the isotope mixture was injected at time 0 and the other half was injected at either 2 or $3 \mathrm{~h}$ for 4-h or 6-h experiments, respectively. The $\left[{ }^{14} \mathrm{C}\right]$ ornithine had a negligible percentage of radioactivity eluting as Arg on ion exchange chromatography. The $\left[{ }^{3} \mathrm{H}\right]$ ornithine was purified by AG50 ion exchange chromatography with elution of contaminants before and after the Orn peak.

2. Abbreviations used in this paper: ALB, albumin; COLL, collagen; DTT, dithiothreitol; NPC, nonparenchymal cells; PAGE, polyacrylamide gel electrophoresis; TFR, transferrin. 
The $\left[{ }^{3} \mathrm{H}\right] \mathrm{Orn}$ fractions were pooled and evaporated. The isotope was reconstituted immediately before its use.

Protein purification. Blood samples were obtained for purification of serum proteins. Serum $(0.2 \mathrm{ml})$ was diluted $1: 5$ with distilled water and applied to a 2-ml affigel-blue column. $5 \mathrm{ml}$ of $0.05 \mathrm{M}$ Tris, $5 \mathrm{mM}$ EDTA, $\mathrm{pH} 7.5$ was passed through the column. Then the column was washed with the same buffer containing $0.5 \mathrm{M} \mathrm{NaCl}$. The ALB fraction was eluted with buffer containing $4.5 \mathrm{M} \mathrm{NaCl}$ and the elution was monitored by spectroscopy at $280 \mathrm{~nm}$ and measurement of radioactivity by liquid scintillation spectroscopy.

Portions of serum $(1 \mathrm{ml})$ were passed through a $0.9 \times 10 \mathrm{~cm}$ protein A-agarose column and washed with $70 \mathrm{ml}$ of $50 \mathrm{mM}$ Tris, $4 \mathrm{mM}$ EDTA, $\mathrm{pH} 7.5$ at a flow rate of $0.6 \mathrm{ml} / \mathrm{min}$. The $\gamma$-globulin fraction was eluted between 3 and $8 \mathrm{ml}$ with $0.2 \mathrm{~N}$ sodium citrate, $\mathrm{pH} 2.2$, and precipitated with $66 \%$ ethanol at $-20^{\circ} \mathrm{C}$. The precipitate was dissolved in $2 \mathrm{ml}$ of 50 $\mathrm{mM}$ Tris, 4 mM EDTA, pH 7.5 and passed through a 5-ml affigel column to remove any contaminating ALB. The $\gamma$-globulin free serum was reacted with rabbit-anti rat TFR antibody for $2 \mathrm{~h}$ at $25^{\circ} \mathrm{C}$. The TFR-antibody complex was purified by affinity to a protein A column as described above.

Hepatic collagen purification. Purification of hepatic collagen (1, 2, 15) was performed as follows. After the animals were sacrificed with an ether overdose the liver was immediately removed and suspended in icecold buffer containing $50 \mathrm{mM}$ Tris, $15 \mathrm{mM}$ EDTA, $1 \mathrm{M} \mathrm{NaCl}, 1 \mathrm{mM}$ PMSF, 5 mM NEM, pH 7.5 (buffer A). The liver was homogenized at speed setting 7 for $1 \mathrm{~min}$ at $4^{\circ} \mathrm{C}$ in a Sorvall Omni Mixer (E. I. Du Pont de Nemours \& Co., Inc., Wilmington, DE). The suspension was washed several times with buffer $A$ and centrifuged at $3,000 \mathrm{~g}, 4^{\circ} \mathrm{C}$ for $30 \mathrm{~min}$. The precipitate was dissolved in $0.5 \mathrm{~N}$ acetic acid containing pepsin (10 $\mathrm{mg} / \mathrm{g}$ ) and incubated at $4^{\circ} \mathrm{C}$ for $6 \mathrm{~h}$ with stirring. The suspension was spun at $3,000 \mathrm{~g}, 4^{\circ} \mathrm{C}$ for $1 \mathrm{~h}$ and the supernatant adjusted to $\mathrm{pH} 7.5$ with $2 \mathrm{~N} \mathrm{NaOH}$. The pepsin digestion was repeated two more times. The supernatants were combined and precipitated with $\left(\mathrm{NH}_{4}\right)_{2} \mathrm{SO}_{4}, \mathrm{pH}$ $8(176 \mathrm{mg} / \mathrm{ml})$. After centrifugation at $3,000 \mathrm{~g}, 4^{\circ} \mathrm{C}$ for $1 \mathrm{~h}$, the precipitate containing collagen was further purified by a second $\left(\mathrm{NH}_{4}\right)_{2} \mathrm{SO}_{4}$ precipitation $(176 \mathrm{mg} / \mathrm{ml})$. After the second $\left(\mathrm{NH}_{4}\right)_{2} \mathrm{SO}_{4}$ precipitation, the precipitates were washed with $10 \mathrm{ml} 70 \%$ ethanol and dissolved in $0.1 \mathrm{~N}$ $\mathrm{NaOH}$.

Hepatic collagen purification was assessed by gel filtration (16); the sample was applied to a $10-\mathrm{ml}$ A $0.5 \mathrm{~m}$ column equilibrated with $0.2 \mathrm{~N}$ $\mathrm{NaCl}, 1 \mathrm{mM}$ PMSF, $0.05 \mathrm{M}$ Tris, pH 7.5. Fractions $(0.7 \mathrm{ml})$ were collected at a flow rate of $0.35 \mathrm{ml} / \mathrm{min}$; elution of proteins was monitored using dual label techniques (17-20). SDS-polyacrylamide gel electrophoresis (PAGE) was used to assess protein purification (21). A vertical slab gel (LKB Instruments, Inc., Gaithersburg, MD) was employed with SDS buffer on a discontinuous system. Samples that were reduced were boiled $2 \mathrm{~min}$ with $100 \mathrm{mM}$ dithiothreitol (DTT). Electrophoresis was carried out at $45 \mathrm{~mA}$ for $2 \mathrm{~h}$. Identification of bands was done with either $0.25 \%$ Coomassie dye in $50 \%$ methanol, $10 \%$ acetic acid, or silver staining, using protein standards. In addition, collagen was identified by its sensitivity to purified bacterial collagenase as previously described (22).

Isolation of hepatocytes and nonparenchymal cells. After the labeling period, animals were anesthesized intramuscularly with a mixture containing $0.1 \mathrm{mg}$ of acepromazine, $11 \mathrm{mg}$ of ketamine, and $0.6 \mathrm{mg}$ zylazine. For isolation of nonparenchymal cells, the following procedure was used $(23,24)$. The liver was perfused via the portal vein with $60 \mathrm{ml}$ of Ringers lactate, $\mathrm{pH} 7.5(10 \mathrm{ml} / \mathrm{min})$ and then with the addition of $0.2 \%$ pronase to $60 \mathrm{ml}$ of buffer and finally with $0.1 \%$ pronase in $100 \mathrm{ml}$ of buffer. The liver was removed, cut in small pieces, and further digested with $0.1 \%$ pronase, Ringers lactate at $37^{\circ} \mathrm{C}$ for $1 \mathrm{~h}$, maintaining the $\mathrm{pH}$ at 7.4 with $2 \mathrm{~N} \mathrm{NaOH}$. The cells were filtered through a cotton gauze and spun at $450 \mathrm{~g}$ for $7 \mathrm{~min}$ at $21^{\circ} \mathrm{C}$. The cells were resuspended in $10 \mathrm{ml}$ of Ringers and separated on a double layered metrizamide gradient (18 and $13 \%$ ). The gradient was centrifuged at $750 \mathrm{~g}, 21^{\circ} \mathrm{C}$ for $17 \mathrm{~min}$. The metrizamide top layer and $15 \mathrm{ml}$ of the metrizamide middle layer were carefully removed. Both fractions were diluted with Ringers and collected by centrifugation at $750 \mathrm{~g}$ for $15 \mathrm{~min}$. The cells were lysed in the Ringers containing $0.1 \%$ SDS and boiled for 2 min. Proteins were precipitated with $66 \%$ ethanol at $-20^{\circ} \mathrm{C}$. Albumin contamination was largely eliminated by extensive chromatography on an affigel blue column.

For isolation of hepatocytes a 16-gauge catheter was inserted into the portal vein and $100 \mathrm{ml}$ of $\mathrm{Ca}^{2+}$-free Hanks' buffer $\left(37^{\circ} \mathrm{C}\right)$ was perfused at $10 \mathrm{ml} / \mathrm{min}(25,26)$. Then $100 \mathrm{ml}$ of the buffer containing $0.7 \mathrm{mg} / \mathrm{ml}$ of collagenase was infused and recirculated for $20 \mathrm{~min}$. The liver was removed and suspended in the collagenase solution with shaking for 10 $\mathrm{min}$. The suspension was applied to a metrizamide gradient as described above. Only a lower layer of hepatocytes was recovered. The hepatocytes were lysed in $0.1 \%$ SDS by sonication with a microprobe. Proteins were precipitated with $66 \%$ ethanol at $-20^{\circ} \mathrm{C}$ twice and collected by centrifugation at $3,000 \mathrm{~g}, 4^{\circ} \mathrm{C}$ for $30 \mathrm{~min}$.

Amino acid analyses. Proteins were hydrolyzed in $6 \mathrm{~N} \mathrm{HCl}$ at $120^{\circ} \mathrm{C}$ for $3 \mathrm{~h}$ (22) and evaporated to dryness. The low molecular weight fractions of sera and tissues (66\% ethanol supernatants) were evaporated to dryness dissolved in distilled water and the amino acids were further purified on a P2 column. Amino acid analyses were performed on a filtered $1 \times 45$ cm AG50W- $\times 8$ column at $50^{\circ} \mathrm{C}$ equilibrated with $0.7 \mathrm{~N}$ sodium citrate, pH 8.6, containing $0.1 \%$ Brij 35. Samples were resuspended in $0.1 \mathrm{~N}$ sodium citrate, $0.1 \%$ Brij 35, $\mathrm{pH} 2.2$, applied to the column, and eluted at a flow rate of $1 \mathrm{ml} / \mathrm{min}$ collecting $4 \mathrm{ml}$ fractions. After $120 \mathrm{ml}$ of 0.7 $\mathrm{N}$ sodium citrate, $\mathrm{pH}$ 8.6, elution of Arg was accomplished using $0.2 \mathrm{~N}$ $\mathrm{NaOH}$. Radioactivity was measured, after adding $14 \mathrm{ml}$ of ACS, in a Mark III scintillation counter with automatic correction for spillover of ${ }^{14} \mathrm{C}$ radioactivity into the ${ }^{3} \mathrm{H}$ channel and efficiencies.

Hepatocyte contribution to hepatic collagen production. After animals were injected with an isotope mixture containing $\left[{ }^{3} \mathrm{H}\right]$ Pro and $\left[{ }^{14} \mathrm{C}\right]$ Orn (or $\left[{ }^{14} \mathrm{C}\right]$ Pro and $\left[{ }^{3} \mathrm{H}\right] \mathrm{Orn}$ ), the relative contribution of hepatocytes to hepatic collagen production in vivo was determined by a dual-label method by comparing the ratio of $\left[{ }^{3} \mathrm{H}\right] \mathrm{Pro} /\left[{ }^{14} \mathrm{C}\right] \mathrm{Arg}$ (or $\left[{ }^{14} \mathrm{C}\right] \mathrm{Pro} /\left[{ }^{3} \mathrm{H}\right] \mathrm{Arg}$ ) in hepatic collagen to the same ratio in albumin. First, we calculated the predicted $\left[{ }^{3} \mathrm{H}\right]$ Pro (or $\left[{ }^{14} \mathrm{C}\right]$ Pro) radioactivity in hepatic collagen produced by hepatocytes, by the following formula:

Hepatocyte $\left[{ }^{3} \mathrm{H}\right]$ Procoll

$=\left[{ }^{14} \mathrm{C}\right] \mathrm{Arg}_{\mathrm{COLL}} \times \frac{\left[{ }^{3} \mathrm{H}\right] \mathrm{PrO}_{\mathrm{ALB}}}{\left[{ }^{14} \mathrm{C}\right] \mathrm{Arg}_{\mathrm{ALB}}} \times \frac{(\text { Pro }[+\mathrm{Hyp}] / \text { Arg })_{\mathrm{COLL}}}{(\text { Pro } / \text { Arg })_{\text {ALB }}}$.

The ratio of (Pro[+Hyp]:Arg) is $~ 3.5$ times greater in hepatic collagen than in ALB $(3,11,27)$.

The relative contribution of hepatocytes to hepatic collagen production was calculated by the following formula:

Hepatocyte contribution $(\%)=\frac{\text { Hepatocyte }\left[{ }^{3} \mathrm{H}\right] \text { Pro }_{\text {CoLL }}}{\text { Hepatic }\left[{ }^{3} \mathrm{H}\right] \text { Pro }_{\text {CoLL }}} \times 100$.

The nonparenchymal cells (NPC) collagen production was determined as follows:

NPC $\left[{ }^{3} \mathrm{H}\right]$ Pro $_{\text {coll }}=$ Hepatic $\left[{ }^{3} \mathrm{H}\right]$Pro$_{\text {coll }}-$ Hepatocyte $\left[{ }^{3} \mathrm{H}\right]$ Procoll.

\section{Results}

In the first series of experiments we analyzed the composition of labeled amino acids, by ion exchange chromatography of purified serum ALB, our index hepatocyte protein. We found that between 60 and $90 \%$ of the label derived from Orn was present as Arg, while the remainder was found in Pro and related aminoacids (probably Glu and Asp) (Fig. 1). We achieved a linear increase in serum ALB specific activity for up to $6 \mathrm{~h}$, maximal period of labeling used in our experiments.

When purified serum TFR was analyzed, we found a pattern of labeled amino acids similar to that observed in ALB (Fig. 2). This would be expected for proteins such as ALB and TFR that have a similar Pro/Arg ratio (27), and that are produced exclusively by the hepatocyte $(13,14)$. Indeed, the distribution of labeled amino acids in TFR was essentially the same as in ALB, 


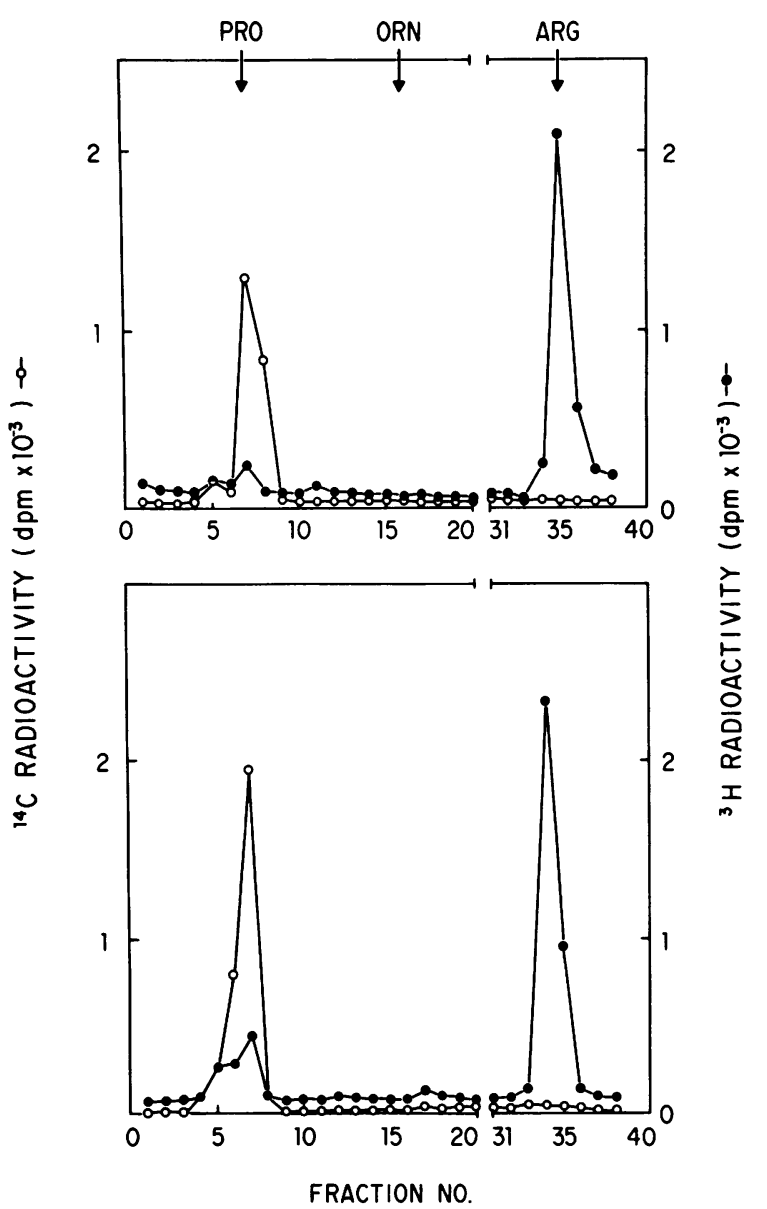

Figure 1. Analysis of labeled amino acids in serum albumin. After intraperitoneal injection of an isotope mixture containing $100 \mu \mathrm{Ci}$ of $\left[{ }^{14} \mathrm{C}\right]$ Pro and $200 \mu \mathrm{Ci}$ of $\left[{ }^{3} \mathrm{H}\right] \mathrm{Orn}$, blood samples were obtained at 2 (top) and $4 \mathrm{~h}$ (bottom) and serum ALB purified on an affigel-blue column. Hydrolyzates of ALB in $0.2 \mathrm{~N}$ sodium citrate, $0.1 \% \mathrm{Brij} 35, \mathrm{pH}$ 2.2 were applied to a $1 \times 45 \mathrm{~cm} \mathrm{AG50} \mathrm{column}$, and eluted at $50^{\circ} \mathrm{C}$ with $120 \mathrm{ml}$ of $0.7 \mathrm{~N}$ sodium citrate, $0.1 \%$ Brij 35 , pH 8.6, and then with $0.2 \mathrm{~N} \mathrm{NaOH}$. Flow rate was $1 \mathrm{ml} / \mathrm{min}$ and $4-\mathrm{ml}$ fractions were collected. Elution of Pro, Orn, and Arg was as indicated. Radioactivity was measured by liquid scintillation spectroscopy.

as shown in Fig. 3, for the ratios of $\left[{ }^{3} \mathrm{H}\right] \mathrm{Pro} /\left[{ }^{14} \mathrm{C}\right] \mathrm{Arg}(103 \pm 6 \%)$ and $\left[{ }^{14} \mathrm{C}\right] \mathrm{Arg} /\left[{ }^{14} \mathrm{C}\right]$ total $(99 \pm 5 \%)$. Also, when we injected $\left[{ }^{14} \mathrm{C}\right]$ Pro and $\left[{ }^{3} \mathrm{H}\right]$ Orn to animals, similar ratios of $\left[{ }^{3} \mathrm{H}\right] \mathrm{Arg} /$ $\left[{ }^{14} \mathrm{C}\right]$ Pro $(\sim 1.1)$ and $\left[{ }^{3} \mathrm{H}\right] \mathrm{Arg} /\left[{ }^{3} \mathrm{H}\right]$ total $(\sim 75 \%$ at $4 \mathrm{~h}$ and $\sim 62 \%$ at $6 \mathrm{~h}$ ) were found in ALB and TFR. Furthermore, when we isolated hepatocytes by collagenase perfusion, the hepatocyte proteins also had $\sim 70 \%$ of the label derived from Orn present as Arg (Fig. 4).

Conversely, a small percentage of labeled Arg was found in nonparenchymal cells. We analyzed the free amino acid pool of nonparenchymal cells isolated by pronase perfusion and metrizamide gradient centrifugation. We found in two groups of nonparenchymal cells (Fig. 5), that almost all of the label derived from Orn was present as Orn, Pro, and related amino acids, but a negligible percentage was present as Arg. In addition, we also found a small percentage of labeled Arg in the amino acid pool of serum (Fig. $6 \mathrm{~B}$ ) and extrahepatic tissues (data not shown) as well as in $\gamma$-globulin (Fig. $6 \mathrm{~A}$ ), a major serum protein produced by $B$ lymphocytes (28). Finally, the analysis of labeled amino

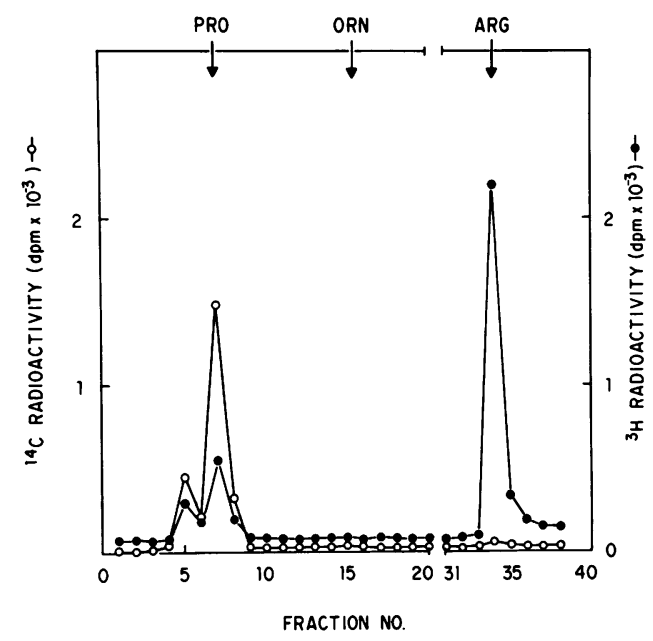

Figure 2. Analysis of labeled amino acids in serum transferrin. Blood samples were obtained at $4 \mathrm{~h}$ in the experiment described in Fig. 1. Serum was passed through a $0.9 \times 10 \mathrm{~cm}$ protein A column to remove $\gamma$-globulin. The $\gamma$-globulin free serum was reacted with anti-rat TFR antibody for $2 \mathrm{~h}$ at $25^{\circ} \mathrm{C}$. The TFR-antibody complex was purified by affinity to a protein A column, and eluted with $0.2 \mathrm{~N}$ sodium citrate, $\mathrm{pH}$ 2.2. Hydrolyzates of TFR were analyzed as described in Fig. 1.

acids in nonparenchymal cell proteins showed that essentially all of the label derived from labeled Orn was found as Pro (and related amino acids) (Fig. 7). These combined findings clearly indicate that spillover of labeled Arg, produced by the hepatocyte, is negligible.

In order to determine whether or not hepatocytes produce collagen in vivo in normal rats, we analyzed the distribution of labeled amino acids in hepatic collagen. We purified hepatic collagen, judging by its characteristics on SDS-PAGE (Fig. 8) and A $0.5 \mathrm{~m}$ chromatography (Fig. 9), and by its susceptibility to purified bacterial collagenase (Figs. 8 and 9). When hydrolyzed hepatic collagen was analyzed on a AG50 column the most important finding was the presence of a sizeable percentage of labeled Arg, derived from the labeled Orn injected into the animals (Fig. 10), which indicates production by the hepatocytes. $\sim 20 \%$ of the radioactivity in hepatic collagen, derived from the label Orn, was present as Arg (Fig. $11 \mathrm{~B}$ ).
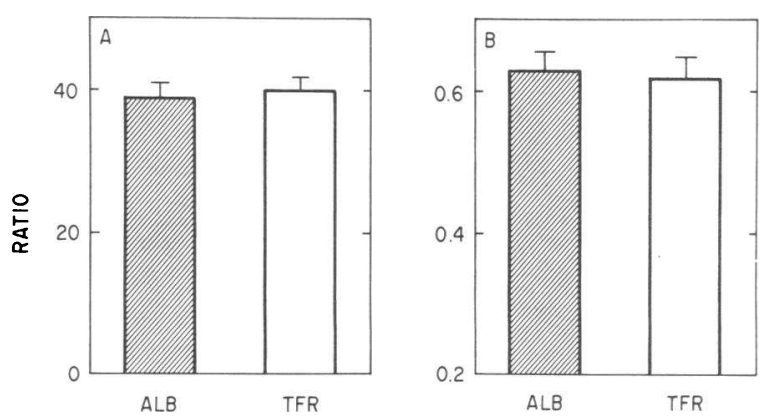

Figure 3. Distribution of labeled amino acids in albumin and transferrin. Animals were injected intraperitoneally with an isotope mixture containing $2 \mathrm{mCi}$ of $\left[{ }^{3} \mathrm{H}\right]$ Pro and $130 \mu \mathrm{Ci}$ of $\left[{ }^{14} \mathrm{C}\right] \mathrm{Orn}$. Blood samples were obtained at $6 \mathrm{~h}$, serum ALB and TFR were purified, and their labeled amino acids were analyzed as described in Figs. 1 and 2 . The ratios of $\left[{ }^{3} \mathrm{H}\right] \operatorname{Pro} /\left[{ }^{14} \mathrm{C}\right] \mathrm{Arg}(A)$ and $\left[{ }^{14} \mathrm{C}\right] \mathrm{Arg} /\left[{ }^{14} \mathrm{C}\right]$ total $(B)$ are shown for $\operatorname{ALB}(n=5)$ and TFR $(n=5)$. Values are mean $\pm \operatorname{SE}$. 


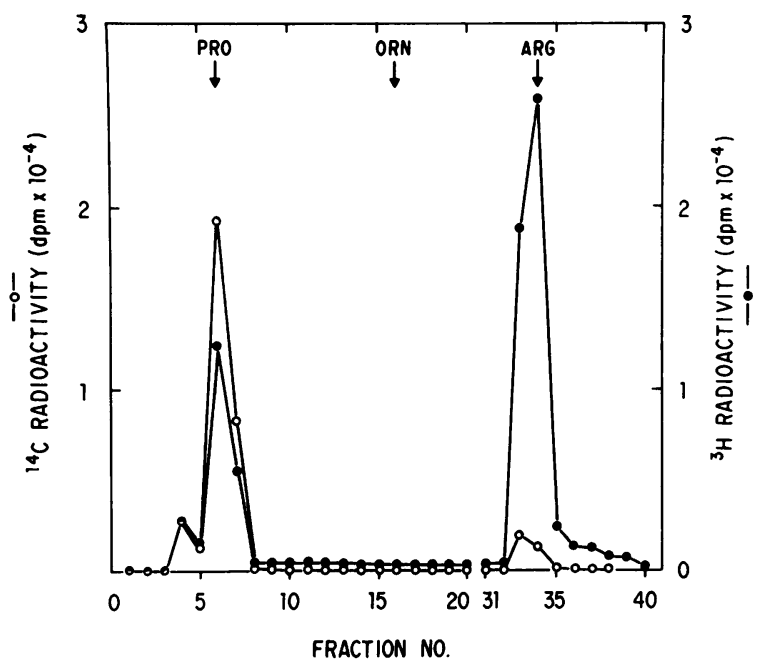

Figure 4. Analysis of labeled amino acids in hepatocyte proteins. After intraperitoneal injection of an isotope mixture containing $100 \mu \mathrm{Ci}$ of $\left[{ }^{14} \mathrm{C}\right]$ Pro and $200 \mu \mathrm{Ci}$ of $\left[{ }^{3} \mathrm{H}\right]$ Orn, hepatocytes were isolated at $4 \mathrm{~h}$ by infusion of collagenase via the portal vein. The hepatocytes were lysed in $0.1 \%$ SDS by sonication and proteins were precipitated with $66 \%$ ethanol. Hydrolyzates of hepatocyte proteins were analyzed as described in Fig. 1.

To what extent do the hepatocytes contribute to hepatic collagen production in vivo? To answer this question, first, it must be remembered that the frequency of $\operatorname{Pro}(+\mathrm{Hyp})$ relative to Arg

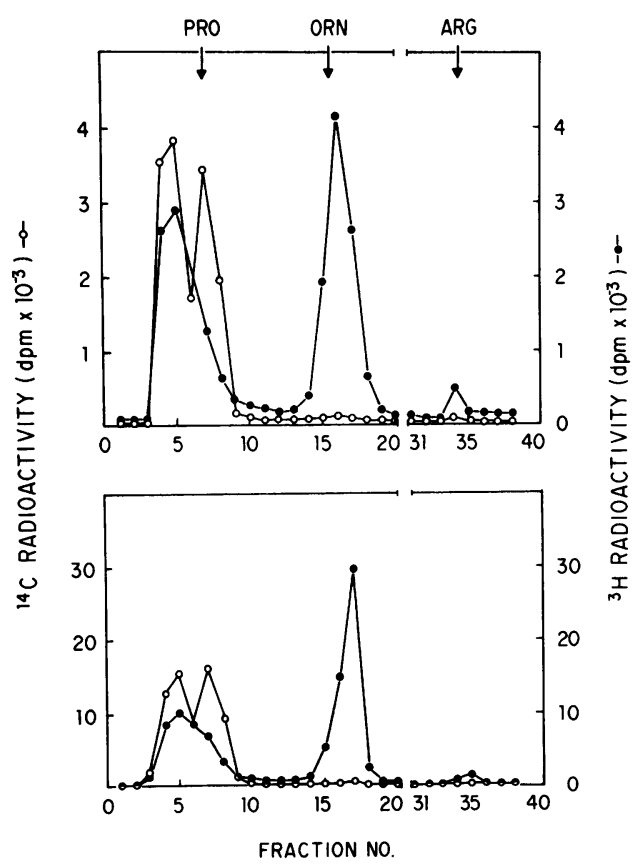

Figure 5. Analysis of labeled amino acids in the free pool of nonparenchymal cells. After the injection of an isotope mixture containing $100 \mu \mathrm{Ci}$ of $\left[{ }^{14} \mathrm{C}\right]$ Pro and $200 \mu \mathrm{Ci}$ of $\left[{ }^{3} \mathrm{H}\right] \mathrm{Orn}$, the liver was perfused at $4 \mathrm{~h}$ via the portal vein with Ringers lactate, $\mathrm{pH} 7.5$ containing $0.2 \%$ pronase $\left(37^{\circ} \mathrm{C}\right)$. The cells were isolated on a double layered metrizamide gradient (18 and $13 \%$ ) at $750 \mathrm{~g}$. Cells on the metrizamide top (top) and metrizamide medium (bottom) layers were lysed in $0.1 \%$ SDS by sonication, and proteins were precipitated with $66 \%$ ethanol. The labeled amino acids in the free pool were analyzed as described in Fig. 1.
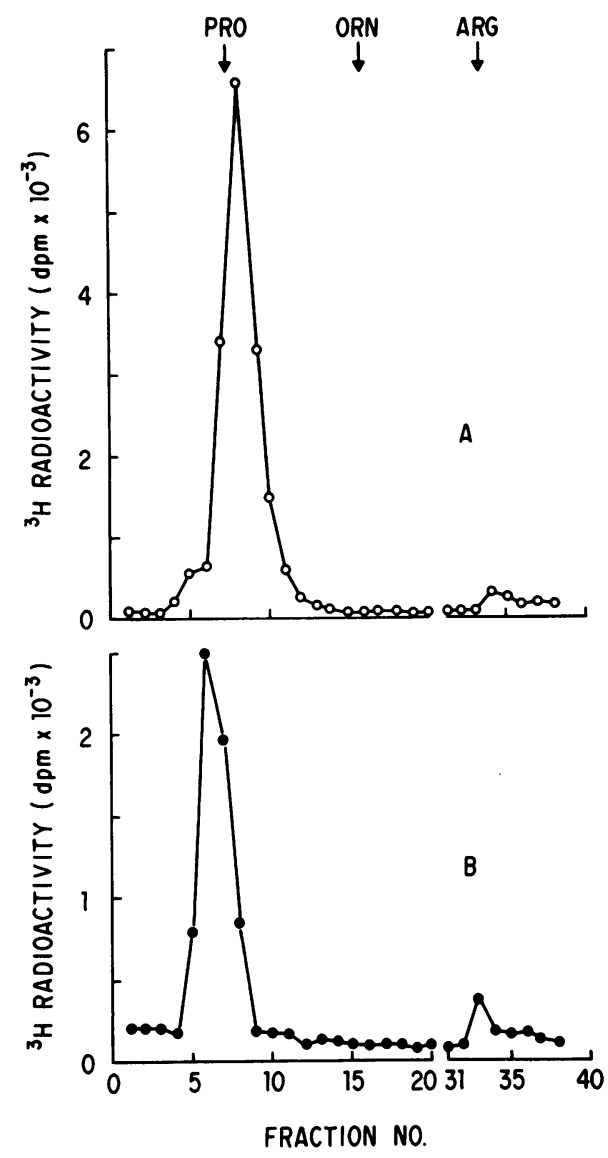

Figure 6. Analysis of labeled amino acids in serum $\gamma$-globulin and in the free pool of serum. $(A)$ After the intraperitoneal injection of $\mathbf{4 0 0}$ $\mu \mathrm{Ci}$ of $\left[{ }^{3} \mathrm{H}\right] \mathrm{Orn}$, serum was obtained at $6 \mathrm{~h}$, and passed through a 0.9 $\times 10 \mathrm{~cm}$ protein A column that was washed with $70 \mathrm{ml}$ of $50 \mathrm{mM}$ Tris, 4 mM EDTA, pH 7.5. The $\gamma$-globulin was eluted with $8 \mathrm{ml}$ of $0.2 \mathrm{~N}$ sodium citrate, $\mathrm{pH} 2.2$, precipitated with $66 \%$ ethanol, and passed through an affigel-blue column to remove any contaminating ALB. Hydrolyzates of $\gamma$-globulin were analyzed as described in Fig. 1. $(B)$ The low molecular weight fraction of serum (66\% ethanol supernatant) was further purified by gel filtration on a P2 column. The labeled amino acids were analyzed as described in Fig. 1.

is $~ 3.5$ times greater in hepatic collagen than in ALB (as calculated from references $3,11,27$ ). Therefore, given the relative frequency of amino acids, we would predict a ratio of $\left[{ }^{3} \mathrm{H}\right] \mathrm{Pro} /$ $\left[{ }^{14} \mathrm{C}\right]$ Arg (or $\left[{ }^{14} \mathrm{C}\right]$ Pro $/\left[{ }^{3} \mathrm{H}\right] \mathrm{Arg}$ ) $\sim 3.5$ times greater in hepatic

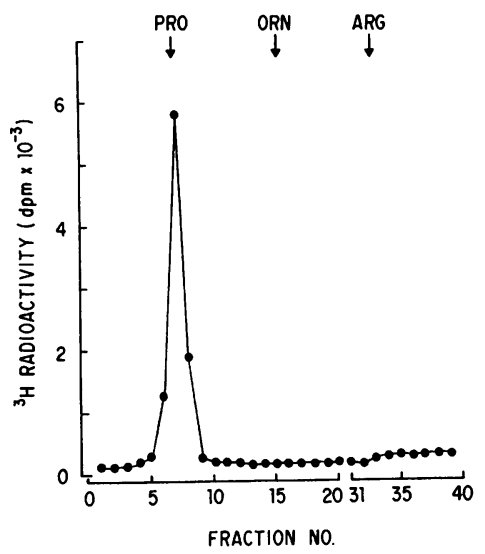

Figure 7. Analysis of labeled amino acids in nonparenchymal cell proteins. Following intraperitoneal injection of $400 \mu \mathrm{Ci}$ of $\left[{ }^{3} \mathrm{H}\right] \mathrm{Orn}$, nonparenchymal cell proteins were obtained as described in Fig. 5, and any contaminating ALB was removed by affigel-blue chromatography. Hydrolyzates of nonparenchymal cell proteins were analyzed as described in Fig. 1. 


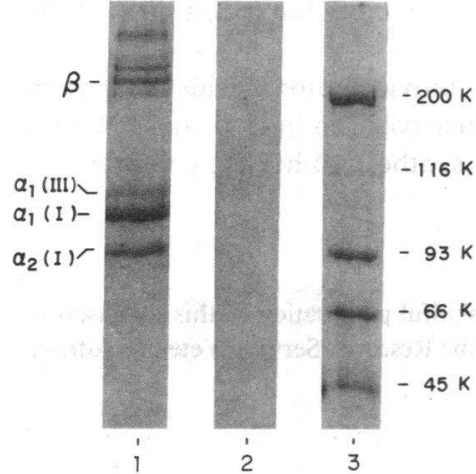

Figure 8. SDS-Polyacrylamide gel electrophoresis of hepatic collagen. Purified hepatic collagen was reduced with $100 \mathrm{mM}$ DTT for $2 \mathrm{~min}$ at $100^{\circ} \mathrm{C}$ (lane 1 ) or pretreated with bacterial collagenase (lane 2). High molecular weight protein markers are also shown (lane 3). The gel was fixed and stained with Coomassie blue as described in Methods.

collagen produced by hepatocytes than in ALB or TFR. In our experiments, the actual ratio of $\left[{ }^{3} \mathrm{H}\right] \mathrm{Pro} /\left[{ }^{14} \mathrm{C}\right] \mathrm{Arg}$ (or $\left[{ }^{14} \mathrm{C}\right] \mathrm{Pro} /$ $\left[{ }^{3} \mathrm{H}\right] \mathrm{Arg}$ ) in hepatic collagen was very close to the predicted ratio (Fig. $11 A$ ). In consequence, our data indicate that the hepatocyte contributes a significant percentage $(88 \pm 8 \%)$ of the newly synthesized hepatic collagen.

\section{Discussion}

The important issue of which cell types are responsible for the in vivo hepatic production of collagen, and to what extent, in normal rats, was not known before this study $(10,11)$. It has been suggested that hepatocytes (4-6) and nonparenchymal cells, including fibroblasts (7), myofibroblasts (9), and sinusoidal cells $(4,8)$, may all play a role in the excessive collagen production of cirrhosis. However, the evidence available to incriminate any one of these cell types in the pathogenesis of hepatic fibrosis, is based only on morphological observations $(5,29)$ or in vitro determination of connective tissue protein production (4-9).

Using indirect immunofluorescence techniques, Diegelmann and co-workers (5) concluded that only under pathological conditions, such as experimental bile duct ligation, does the hepatocyte produce type IV collagen. This phenomenon was not observed under normal physiological conditions. Even with electron immunohistochemical studies, Martinez-Hernandez (30) was unable to determine in normal rats which cells were responsible for the synthesis of collagen types I, IV, laminin, and fibronectin. Nonetheless, in rats with carbon-tetrachloride-induced cirrhosis, collagen I was identified in the endoplasmic reticulum of he-

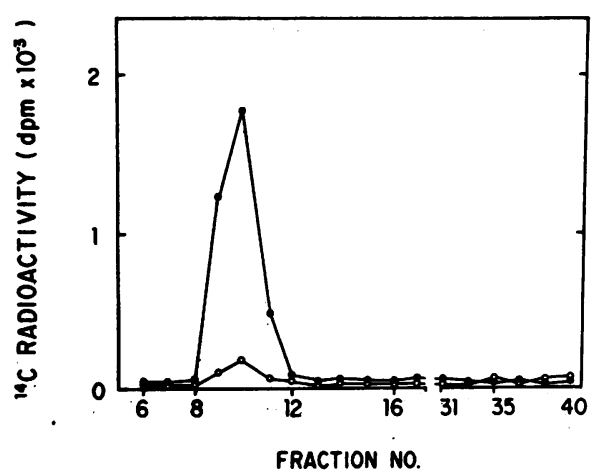

Figure 9. Gel filtration of hepatic collagen. Purified hepatic collagen was applied with (0) or without (0) collagenase pretreatment to an A $0.5 \mathrm{~m}$ column as described in Methods.

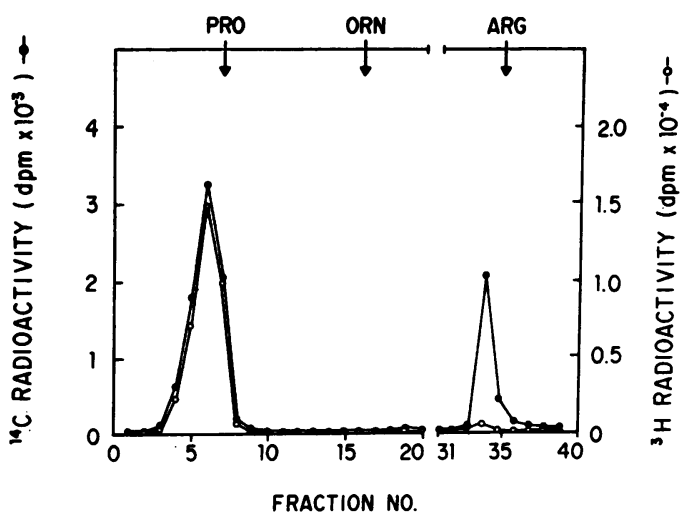

Figure 10. Analysis of labeled amino acids in hepatic collagen. After the intraperitoneal injection of an isotope mixture containing $2 \mathrm{mCi}$ of $\left[{ }^{3} \mathrm{H}\right]$ Pro and $130 \mu \mathrm{Ci}$ of $\left[{ }^{14} \mathrm{C}\right] \mathrm{Orn}$, hepatic COLL was purified at 6 h. Hepatic COLL was extracted from 3,000 $\mathrm{g}$ in Fig. 1. Hepatic COLL was extracted from $3,000 \mathrm{~g}$ precipitates of liver homogenates (in 50 mM Tris, 15 mM EDTA, $1 \mathrm{M} \mathrm{NaCl}, 1 \mathrm{mM}$ PMSF, $5 \mathrm{mM}$ NEM, pH $7.5)$ in $0.5 \mathrm{~N}$ acetic acid with pepsin $(10 \mathrm{mg} / \mathrm{g})$ for $6 \mathrm{~h}$ at $4^{\circ} \mathrm{C}$, three times. The combined $3,000 \mathrm{~g}$ supernatants were precipitated twice with $\left(\mathrm{NH}_{4}\right)_{2} \mathrm{SO}_{4}(176 \mathrm{mg} / \mathrm{ml})$. Hydrolyzates of hepatic COLL were analyzed as described in Fig. 1.

patocytes, while collagen IV was found in endothelial, smooth muscle, and Ito cells (31).

The approach used in this study provides information in normal rats regarding the cell type responsible for the production of hepatic collagen. In addition, the new method offers the possibility of assessing hepatocyte contribution to fibrogenesis in cirrhosis. The rationale for our method is that only in the hepatocyte is labeled Orn converted, via the urea cycle, to labeled Arg. Note that Orn is not incorporated into proteins. Our data clearly indicate that hepatocytes rapidly metabolized the labeled Orn to labeled Arg which is incorporated into ALB, TFR, and hepatocyte proteins. Conversely, only a small percentage of the radioactivity was present as Arg in the free amino acid pool of nonparenchymal cells, serum, and extrahepatic tissues, as well
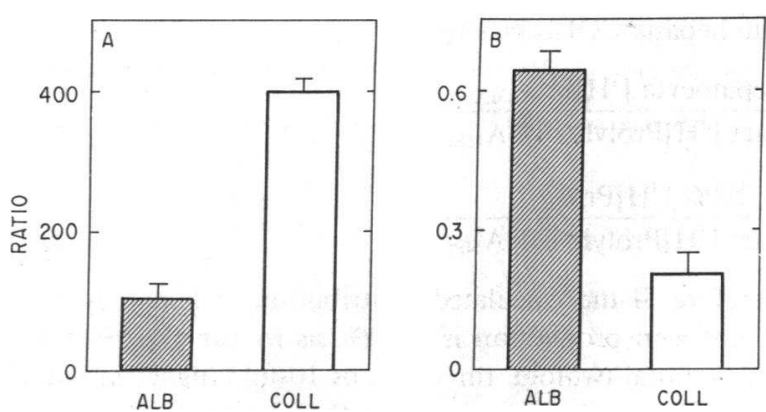

Figure 11. Distribution of labeled amino acids in albumin and hepatic collagen. Animals were injected intraperitoneally with an isotope mixture containing either $2 \mathrm{mCi}$ of $\left[{ }^{3} \mathrm{H}\right]$ Pro and $130 \mu \mathrm{Ci}$ of $\left[{ }^{14} \mathrm{C}\right] \mathrm{Orn}$, or $400 \mu \mathrm{Ci}$ of $\left[{ }^{\mathrm{i}} \mathrm{C}\right]$ Pro and $400 \mu \mathrm{Ci}$ of $\left[{ }^{3} \mathrm{H}\right]$ Orn. After $6 \mathrm{~h}$, serum ALB and hepatic COLL were purified as described in Fig. 1 and Fig. 10, respectively. Hydrolyzates of ALB and hepatic COLL were analyzed as described in Fig. 1. The ratios of labeled Pro/labeled Arg (expressed as a percentage of ALB values) $(A)$ and of labeled Arg/total radioactivity derived from labeled $\operatorname{Orn}(B)$ are shown. Values are mean \pm SE for $\operatorname{ALB}(n=5)$ and COLL $(n=5)$. 
as in nonparenchymal cell proteins and $\gamma$-globulin. These findings indicate that spillover of labeled Arg from the hepatocytes is negligible.

From the $\left[{ }^{3} \mathrm{H}\right] \mathrm{Pro} /\left[{ }^{14} \mathrm{C}\right] \mathrm{Arg}$ ratio in ALB we accurately predicted a similar ratio in TFR since the ratio of Pro/Arg is almost the same in both proteins (27), and they are exclusively produced by the hepatocytes $(13,14)$. We found a sizeable percentage of the radioactivity derived from labeled Orn as Arg, in purified hepatic collagen, which indicates production by the hepatocyte. Given the sensitivity of our methods and the relative frequency of Pro(+Hyp):Arg in hepatic collagen and $\operatorname{ALB}(3,11,27)$, our data indicate that in normal rats most of the hepatic collagen is produced by the hepatocytes.

Although the dual-label method was accurate irrespective of variation in the ${ }^{3} \mathrm{H} /{ }^{14} \mathrm{C}$ ratio in ALB and TFR, for hepatic collagens which are produced at lower rates and have a lower frequency of Arg relative to Pro, as compared with ALB, enough labeled Orn should be injected to minimize potential errors when analyzing the distribution of labeled amino acids.

Potential sources of error in our method include variable contamination of purified proteins with hepatocyte proteins, in particular, ALB. A large percentage of ALB contamination can be eliminated by affigel-blue chromatography. In addition, extensive purification of hepatic collagen is required since a relative small contamination with proteins of higher specific activity could introduce significant errors in the analysis of labeled amino acids. Another potential source of error in our method is the contamination of purified proteins with radioactive free Arg. However, the absence of radioactive Orn in the protein hydrolyzates argues strongly against that possibility. In the analysis of amino acids, column overloading with either peptides (following incomplete hydrolysis) or amino acids could lead to elution of radioactivity in the Arg region. However, in these instances, the spurious co-elution of labeled Pro with Arg will be detected.

We emphasize that our method estimates relative contribution of hepatocytes (HEP) and nonparenchymal cells (NPC) toward hepatic collagen (COLL) production based on the ratios of labeled Pro and Arg, as described in Methods. However, to determine the contribution of hepatocytes and nonparenchymal cells to hepatic collagen production in molar terms, the following equation would be required:

Absolute hepatic COLL production

$$
\begin{aligned}
& =\frac{\text { Hepatocyte }\left[{ }^{3} \mathrm{H}\right] \text { Pro }_{\text {CoLL }}}{\text { Sp. act }\left[{ }^{3} \mathrm{H}\right] \text { Prolyl- } t-\text { RNA }_{\text {HEP }}} \\
& +\frac{\text { NPC }\left[{ }^{3} \mathrm{H}\right] \text { Pro }_{\text {CoLL }}}{\text { Sp. act }\left[{ }^{3} \mathrm{H}\right] \text { Prolyl- } t-\text { RNA }_{\text {NPC }}} .
\end{aligned}
$$

Therefore, if the calculated contribution of hepatocyte to hepatic collagen production is $\sim 90 \%$, as in our experiments, even an eventual twofold, threefold, or 10-fold higher prolyl- $t$ RNA specific activity in hepatocytes than in nonparenchymal cells would bring the hepatocyte contribution in molar terms to 82,75 , and $47 \%$, respectively. We were unable to measure the prolyl-t-RNA specific activity in isolated nonparenchymal cells, even by using the sensitive $\left[{ }^{14} \mathrm{C}\right]$ dansyl- $\mathrm{Cl}$ method $(32,33)$. The extensive procedure required to isolate nonparenchymal cells may affect the stability of the aminoacyl- $t$-RNA.

However, since our results indicate that most of the labeled hepatic collagen is contributed by hepatocytes, even a large difference in the prolyl-t-RNA specific activity of hepatocyte and nonparenchymal cells would not modify the conclusions of the study.

In conclusion, this study provides direct evidence that in normal rats hepatocytes produce collagen in vivo, and that they contribute most of the newly synthesized hepatic collagen.

\section{Acknowledgments}

We thank Gary Deming for his skillful preparation of this manuscript. This study was supported by the Research Service, Veterans Administration.

\section{References}

1. Seyer, J. M., E. T. Hutcheson, and A. H. Kang. 1977. Collagen polymorphism in normal and cirrhotic human liver. J. Clin. Invest. 59: 241-248.

2. Rojkind, M., M.-A. Giambrone, and L. Biempica. 1979. Collagen types in normal and cirrhotic liver. Gastroenterology. 76:710-719.

3. Seyer, J. M. 1980. Interstitial collagen polymorphism in rat liver with $\mathrm{CCl}_{4}$-induced cirrhosis. Biochim. Biophys. Acta. 629:490-498.

4. Tseng, S. C. G., P. C. Lee, P. F. Ells, D. M. Bissell, E. A. Smuckler, and R. Stern. 1982. Collagen production by rat hepatocytes and sinusoidal cells in primary monolayer culture. Hepatology. 2:13-18.

5. Diegelmann, R. F., P. S. Guzelian, R. Gay, and S. Gay. 1983. Collagen formation by the hepatocyte in primary culture and in vivo. Science (Wash. DC). 219:1343-1345.

6. Tseng, S. C. G., E. A. Smuckler, and R. Stern. 1983. Types of collagen synthesized by normal rat liver hepatocytes in primary culture. Hepatology. 3:955-963.

7. Holt, K., M. Bennett, and M. Chojkier. 1984. Acetaldehyde stimulates collagen and noncollagen protein production by human fibroblasts. Hepatology. 4:843-848.

8. Voss, B., J. Rauterberg, G. Pott, U. Brehmer, S. Allam, R. Lehmann, and D. B. v. Bassewitz. 1982. Nonparenchymal cells cultivated from explants of fibrotic liver resemble endothelial and smooth muscle cells from blood vessel walls. Hepatology. 2:19-28.

9. Savolainen, E.-R., M. A. Leo, R. Timpl, and C. S. Lieber. 1984. Acetaldehyde and lactate stimulate collagen synthesis of cultured baboon liver myofibroblasts. Gastroenterology. 87:777-787.

10. Popper, H., and G. R. Martin. 1982. Fibrosis of the liver. The role of the ectoskeleton. In Progress in Liver Diseases. H. Popper and F. Schaffner, editors. Grune \& Stratton, Inc., New York. 7:133-156.

11. Rojkind, M. 1982. The extracellular matrix. In The Liver Biology and Pathobiology. I. Arias, H. Popper, D. Schachter, and D. A. Shafritz, editors. Raven Press, Inc., New York. 537-548.

12. Powers, S. G., and A. Meister. 1982. In The Liver Biology and Pathobiology. I. Arias, H. Popper, D. Schachter, and D. A. Schafritz, editors. Raven Press, Inc., New York. 251-263.

13. Lane, R. S. 1969. The cellular distribution of albumin in normal rat liver demonstrated by immunofluorescent staining. Clin. Sci. (Lond.). 36:157-159.

14. Lane, R. S. 1968. Transferrin synthesis in the rat. A study using the fluorescent antibody technique. Br. J. Haematol. 15:355-364.

15. Trelstad, R. L. 1982. Native collagen fractionation. In Immunochemistry of the Extracellular Matrix. H. Furthmayr, editor. CRC Press, Inc., Boca Raton, FL. 1:32-41.

16. Peterkofsky, B. 1982. Bacterial collagenase. Methods Enzymol. 82:453-471.

17. Chojkier, M., J. Bateman, J. M. Phang, and B. Peterkofsky. 1982. Formation of proline metabolites in chick embryo bone. Interference with the measurement of free hydroxyproline by ion-exchange chromatography. Anal. Biochem. 120:330-338.

18. Chojkier, M., B. Peterkofsky, and J. Bateman. 1980. A new method for determining the extent of proline hydroxylation by measuring changes in the ratio of $\left[4-{ }^{3} \mathrm{H}\right]:\left[{ }^{14} \mathrm{C}\right]$ proline in collagenase digests. Anal. Biochem. 108:385-393. 
19. Flaherty, M., and M. Chojkier. $1984 .\left[{ }^{3} \mathrm{H}\right]$ Tryptophan- $\left[{ }^{14} \mathrm{C}\right]$ proline dual label method for the simultaneous determination of collagen and noncollagen protein production. Anal. Biochem. 142:386-394.

20. Chojkier, M., R. Spanheimer, and B. Peterkofsky. 1983. Specifically decreased collagen biosynthesis in scurvy dissociated from an effect on proline hydroxylation and correlated with body weight loss. J. Clin. Invest. 72:826-835.

21. Laemmli, U. K. 1970. Cleavage of structural proteins during the assembly of the head of bacteriophage T4. Nature (Lond.). 227:680-685.

22. Peterkofsky, B., M. Chojkier, and J. Bateman. 1982. Determination of collagen synthesis in tissue and cell culture systems. In Immunochemistry of the Extracellular Matrix. H. Furthmayr, editor. CRC Press, Inc., Boca Raton, FL. 2:19-47.

23. Knook, D. L., N. Blansjaar, and E. Ch. Sleyster. 1977. Isolation and characterization of Kupffer and endothelial cells from rat liver. Exp. Cell Res. 109:317-329.

24. Knook, D. L., A. M. Seffelaar, and A. M. de Leeuw. 1982. Fatstoring cells of the rat liver. Their isolation and purification. Exp. Cell Res. 139:468-471.

25. Hatoff, D. E., and W. G. M. Hardison. 1979. Induced synthesis of alkaline phosphatase by bile acids in rat liver cell culture. Gastroenterology. 77:1062-1067.
26. Hardison, W. G. M., and R. Weiner. 1980. Taurine transport by rat hepatocytes in primary culture. Biochim. Biophys. Acta. 598:145152.

27. Fasman, G. D. 1976. Handbook of Biochemistry and Molecular Biology. Vol 3. CRC Press, Inc., Boca Raton, FL. 505-511.

28. Dutton, R. W., and R. I. Mishell. 1967. Cellular events in the immune response. The in vitro response of normal spleen cells to erythrocyte antigens. Cold Spring Harbor Symp. Quant. Biol. 32:407-414.

29. Nakano, M., T. M. Worner, and C. S. Lieber. 1982. Perivenular fibrosis in alcoholic liver injury. Ultrastructure and histologic progression. Gastroenterology. 83:777-785.

30. Martinez-Hernandez, A. 1984. The hepatic extracellular matrix. I. Electron immunohistochemical studies in normal rat liver. Lab. Invest. 51:57-74.

31. Martinez-Hernandez, A. 1985. The hepatic extracellular matrix. II. Electron immunohistochemical studies in rats with $\mathrm{CCl}_{4}$-induced cirrhosis. Lab. Invest. 53:166-186.

32. Hildebran, J. N., J. Airhart, W. S. Stirewalt, and R. B. Low. 1981. Prolyl- $t$ RNA-based rates of protein and collagen synthesis in human lung fibroblasts. Biochem. J. 198:249-258.

33. Flaherty, M., and M. Chojkier. 1986. Selective inhibition of collagen synthesis by the $\mathrm{Ca}^{2+}$ ionophore, $\mathrm{A} 23187$, in cultured fibroblasts. J. Biol. Chem. In press. 